\title{
RELIGIOSITY AND THE POSITION OF THE QURAN AND THE BIBLE ON THE PERVASIVE CORRUPTION IN NIGERIA
}

\author{
SURAKAT Rafiu Olaniyi \\ Department of Islamic Studies, \\ The College of Education, Lanlate, \\ Oyo State, Nigeria. \\ Email: surakatolaniyi@gmail.com, +2347039391734 \\ OYATOWO Michael Idowu \\ Department of Christian Religious Studies, \\ The College of Education, Lanlate, \\ Oyo State, Nigeria. \\ Email: michealidowu4jesus@gmail.com, +2348060092911
}

\begin{abstract}
The paper seeks to investigate the relationship between the scourge of corruption and its devastating effects on Nigerians and the moral Biblical and Qur'anic injunctions in mitigating corruption, which has been debarring the development of Nigeria as a nation. The practice has unethically empowered some few individuals or perpetrators to corner societal resources for personal enrichment which in its wake brings hardship to the life of many Nigerians. Meanwhile, the government in her efforts at mitigating corrupt tendencies and practices established agencies such as Independent Corrupt Practices and Other Related Offences Commission (ICPC) and Economic and Financial Crime Commission (EFCC). Rather than abating corruption, it is disheartening that it increases various forms of corruption in Nigeria. The paper employed both the theoretical and analytical approaches in explaining the Qur'anic and Biblical injunctions against corruption and its implication on the citizens. The study opines that the problem of corruption increases in Nigeria because both the Biblical and Qur'anic moral injunctions that would help abate corruption were not employed by their adherents especially those in the corridors of powers. It is suggested among others that the religious injunctions deducible from both the Bible and Qur'an should be re-introduced into the system of governance to adjudicate cases of corrupt practices in Nigeria.
\end{abstract}

Keywords: Bible, Corruption, Pervasive, Position, Quran, Religiosity. 


\section{Introduction}

The menace of corruption is internationally wider in scope and monstrous in nature and debarring the development of nation economically, socially andpolitically. Corruption, according to Achebe (1983) is not only pervasive, alarming and endemic, but it leads a nation to a total destruction no matter how such nation is endowed with abundant resources ranging from human to the natural resources. Irrespective of ubiquity and apparent institutionalization of corruption, its effects are still serving as an aberration which no individual wishes to openly associate with. Steps to eradicate corruptions in Nigeria had been taken by various governments, be it Military or democratically elected representatives, but less success has been recorded. The first national attempt for the mitigation against corruption was the enactment of the Criminal Justice Miscellaneous Provision Decree of 1966 by the First and Second Military Heads of State (Bello-Imam, 2004). Notably in the early 70s during the regimes of Muritala and Obasanjo, this was later succeeded by the Corrupt Practices Decree of 1975. The two regimes struggled to wage war against corruption with its Jaji declaration, sequel to the reported level of corruption in Nigeria. The code of Conduct Bureauand Code of Conduct Tribunal were established and replaced to arrest the vice of corruption. The inability of Code of Conduct Bureau and Code of Conduct Tribunal to sanitize and emancipate the nation from vices of corruption influenced the setting up of secret special Military Tribunal to fight the menace of corruption.The second democratic dispensation that succeeded Obasanjo administration ably led by President Uthman Aliyu Shehu Shagari waged his own war against corruption, through his well publicised ethical re-orientation campaign. Shortly after the democratically elected second republic was overthrown in December 31st 1983 by Major General Muhammad Buhari, the new military regime alleged the NPN government led by President Shehu Shagari of poor management of the nation's resources and pervasive corruption in both the public and private sectors of the nation's economy.

However, the new military regime introduced four measures at mitigating the problems of corruption in Nigeria, which include Mass Arrest, Detention and Investigation of political office holders, Mass Purge of the Public Service and Promulgation of Tough Decrees on Act of Indiscipline popularly known as War Against Indiscipline (WAI). After the Mass Arrest, Detention and Investigation of Politicians such as the President himself, the Vice President, all Federal Ministers, the State Governors and their Deputies, the Commissioners who have not being in an exile before the arrest was effected. Then the new military regime set up a Special Military otherwise called Secret Military Tribunal for the purpose of undertaking various investigations across the country, which at the end of the exercise released majority of the arrested politicians including the ousted President and his Deputy.

The Secret Military Tribunal however found some State Governors and other public officials virtually guilty of some alleged offences. Bello-Imam (2004) presents the analysis below for perusal about the alleged and convicted politicians in the Second Republic between 1979-1983 thus; 


\begin{tabular}{|l|l|l|l|l|}
\hline S/N & Name & Alleged Offences & $\begin{array}{l}\text { Jail } \\
\text { Term }\end{array}$ & $\begin{array}{l}\text { Amount to } \\
\text { be } \\
\text { Refunded }\end{array}$ \\
\hline 1. & $\begin{array}{l}\text { Mr. Okilo (Rivers } \\
\text { State Governor) }\end{array}$ & Illegal operation of foreign bank account & 21 years & Nil \\
\hline 2. & $\begin{array}{l}\text { Bakin Zuwo (Kano } \\
\text { State Governor) }\end{array}$ & $\begin{array}{l}\text { Corruption, aiding and abetting; unlawful } \\
\text { enrichment of political party }\end{array}$ & 23 years & 100,000 \\
\hline 3. & $\begin{array}{l}\text { Olabisi V. Onabanjo } \\
\text { (Ogun State Governor) }\end{array}$ & $\begin{array}{l}\text { Unlawful importation of foreign } \\
\text { currencies }\end{array}$ & 15 years & $2,000,000$ \\
\hline 4. & $\begin{array}{l}\text { Adamu Attah (Kwara } \\
\text { State Governor) }\end{array}$ & Corrupt operation of security vote & 21 years & $2,000,000$ \\
\hline 5. & $\begin{array}{l}\text { Masi V. I. (Federal } \\
\text { Minister of Finance) }\end{array}$ & Corruption & 23 years & $1,500,000$ \\
\hline
\end{tabular}

In August 27, 1985 when General Ibrahim Babangida terminated General Buhari's administration, inaugurated a committee on corruption and other economic crimes. While General SanniAbacha finally set up a number of probe panels to fight corruption, most especially Corporate Corruption. In spite of all these efforts, there seemed to be increase in the level of corruption in Nigeria.

Since the existence of Nigeria as a country, the larger percentage of the people have been indirectly forced to live under unfavourable conditions like hunger, poverty, wretchedness, uncurable diseases. Theseugly situations engendered social imbalance which classified the entire nation into two, the rich and poor. Despite the mineral resources God endowed it, the fewindividuals form the clique of putting the wealth under their control through corrupt practices, so as to get their interest protected at all cost.

Corruption is an abominable social evil and could be seen as direct effect of an unjust socio-economic and political order. To crown it all, corruption and other immorality like social injustice are the weapons that the few elites used for the demoralization of the poor masses. Adetunji (2012) explains that "bribery and corruption cause injustice to the citizens of the society in which they operated, he further hints that giving bribes unfairly influence government officials to carry out some incompatible acts with government policies andcorrupting judges to render judicial institution useless. Basheer (1984) adds that when a nation is corrupt, unjust and tyrannical,it deliberately closes the door of intellectual and moral development to some children simply because their parents are poor and are notinfluential. The denial of education to a child is absolutely the gravest of all social injustice.Part of corruption is the discrimination that usually occurs during the provision of job opportunities in the sense that children of the ruling class, elites, and the affluent people have better chances of getting employed in the shortest possible time at the expense of all the laid down procedures, than the children of the common man who are more qualified. Though the children of the ruling class may render incompetent services because they would have passed out of their educational institutions ill-equipped and the sectors that employed them would continue to suffer.

Another destructive effect of corruption is manifested in political participation in Nigeria, where social injustice and atrocities are being performed during the period of election. Since 1999 for example, when the nation has been re-democratised, inequities, selfishness, greediness and self-centeredness have characterized the election process by the miscreant 
politicians by introducing political thuggery, ballot snatching and brigandage to win at all cost in any general election in the country (Richard, 1991). While Philips (1997) buttresses that political corruption involves substituting rule in the interest of an individual or group for those who publicly endorsed the practices. Desire to carry out this research is borne out of curiosity to investigate the reasons why the adherents of the two religions (Islam and Christianity) failed to uphold the mandate of their sacred Books (The Quran and The Bible) so that their faith could be perfected before Almighty God.

\section{The Conceptual Framework on Corruption}

John (2002) traces the origin ofthe word corruption to have come from Latin "Corruptus" (the past participle of the verb 'Corrumpere') meaning 'to destroy'. However, the word is made of 'Cor' and 'rumpere' meaning 'altogether' and 'to break' respectively. Corruption can thus be interpreted as the destruction of order, rules, fairness, rights, norms, value, trust, peace and harmony, love, opportunity, humanity, etc. Scholars such as Bello-Imam (2004) and Bolaji (1970) critically ruminatedon the word corruption and identify the range of acts that constituted corruption to include bribery, extortion, buying an influence, nepotism, favouritism, fraud, embezzlement etc. which are considered to be the evidence of immorality as foundation of failure in Nigeria.

Mahmoud (2011) literally interpretes the word 'corruption' to mean "Fasad" in Arabic language. Making reference to the Holy Qur'an chapter 30 verse 41. Hornby (2001) sees corruption as dishonest or illegal behaviour especially of the people in authority. It further observes the concepts as "the act or effect of making somebody to change from moral to immoral standard of behaviour". Similarly, Mariam Webster (1990) defines corruption as "inducement offered to someone by improper or unlawful means such as bribery".

Bello-Imam (2004) further cites the World Bank position on corruption as "the use of public office through the instrumentality of private agents who actively offer bribes to circumvent public policies and processes for competitive advantage and profit.He equally alludes that beyond bribery and corruption, public office can also be abused for personal benefit through patronage and nepotism, theft of state assets or diversion of state revenues". Bolaji (1970) sees corruption as "the act of money-giving and money-taking to induce the receiver to carryout an action in favour of the giver who is not in actual fact entitled to the benefit of that action. Finally, Wolf and Gurgen (2000) summarized corruption as the betrayal and abuse of trust for private benefits.

Observing the meaning of the copious definitions of the word corruption given above, it embraces all manner of abuse of public office/authority which is not restricted to only the monetary reward, rather,it covered the misuse of authority as a result of consideration of personal gains. So, the emphases of these definitions therefore, are the conception of the vices of corruption as the selfish enrichment of someone and inordinate ambitions to accumulate wealth at the expense of others in the society.

\section{The Genesis of Corruption in Nigeria}

Corruption is as old as man himself, because man's appearance on the face of the earth, brought to the fore his physiological needs: food, clothing and shelter on his daily priority list. Having started to spend days, months and years, he started developing interest in wealth accumulations and desires, thereby experiencing economic hardship and inability of his meagre resource to satisfy his needs. Those that were contented between their demand and supply, did not resort to dishonest and illegal behaviour to meet their shortfall, but those who were 
discontented with the situation resorted to dishonesty and unauthorized behaviour to satisfy their shortfall and their individual desires. So, this could explain how corruption started to get its way in the society (Shehu, 1997).

Richard (1991) aptly remarked that "undoubtedly, bribery, gratification and nepotism are the manifestation of the vices that have geared up researchers on the menace of corruptions in Africa. Irrespective of this awareness, the vices have grown from strength to strength. The unfolding picture of corruption in Nigerian public life is disheartening, because successive governments have attempted to put in place various mechanism to arrest its growth, but the reverse is the case. Specifically, in 1952, the Emir of Gwandu was so worried about the level of corruption in the Northern Nigeria that he had to move the following motion on the floor of the Northern House of Chiefs as quoted by Paolo (1997) thus: that this House, agreeing that bribery and corruption are widely prevalent in all walks of life, recommends that Native Authorities should make efforts to trace and punish offenders with strict impartiality and to educate public opinion against bribery and corruption".

Meanwhile, the type of corruption which Wraith and Simpkings (1963) observed about 39 years ago can be likened to a child's play compared with the level of corruption prevalent in this contemporary Nigeria. Corruption in Africa and particularly in Nigeria, has grown beyond imagination and to a degree which is bothering the minds of the poor masses. Study the table 2 below and compare with the table 1 earlier presented, it is enough and evidence to substantiate the point made by Wraith and Simpkings (1963) about the present level of corruption we are now witnessing in Nigeria context.

The table 2 below showcases some convicted leaders in Nigeria between1999-2015 thus:

\begin{tabular}{|c|c|c|c|c|}
\hline $\mathbf{S} / \mathbf{N}$ & Name & Political Status & $\begin{array}{c}\text { Offence } \\
\text { Committed }\end{array}$ & $\begin{array}{c}\text { Awarded } \\
\text { Punishment }\end{array}$ \\
\hline 1. & $\begin{array}{l}\text { James } \quad \text { Onanefe } \\
\text { Ibori }\end{array}$ & $\begin{array}{l}\text { Delta State Governor } \\
1999-2007\end{array}$ & $\begin{array}{l}\text { Money Laundering } \\
\text { of } \$ 250 \mathrm{~m}\end{array}$ & $\begin{array}{l}\text { 13years } \\
\text { Imprisonment }\end{array}$ \\
\hline 2. & $\begin{array}{l}\text { Revd. Jolly Tavoro } \\
\text { Nyame }\end{array}$ & $\begin{array}{l}\text { Governor of Taraba } \\
\text { State 1999-2007 }\end{array}$ & $\begin{array}{l}\text { Misappropriation of } \\
\$ 1.64 \mathrm{bn}\end{array}$ & $\begin{array}{l}14 \text { Years } \\
\text { Imprisonment }\end{array}$ \\
\hline 3. & Jonah David Jang & $\begin{array}{l}\text { Governor of Plateau } \\
\text { State 2007-2015 }\end{array}$ & Diversion of $¥ 6.3 \mathrm{bn}$ & $\begin{array}{l}21 \text { Years } \\
\text { Imprisonment }\end{array}$ \\
\hline 4. & $\begin{array}{l}\text { Joshua } \quad \text { Chibi } \\
\text { Dariye }\end{array}$ & $\begin{array}{l}\text { Governor of Plateau } \\
\text { State 1999-2007 }\end{array}$ & $\begin{array}{l}\text { Misappropriation of } \\
\text { the state ecological } \\
\text { funds of } 1.162 \mathrm{bn}\end{array}$ & $\begin{array}{l}14 \text { Years } \\
\text { Imprisonment }\end{array}$ \\
\hline 5. & Bala James Ngilari & $\begin{array}{l}\text { Governor of Adamawa } \\
\text { State }\end{array}$ & $\begin{array}{l}\text { Failure to adhere to } \\
\text { the procurement law } \\
\text { of the state }\end{array}$ & $\begin{array}{l}5 \text { Years } \\
\text { Imprisonment }\end{array}$ \\
\hline 6. & Lucky Igbinedion & Edo State Governor & $\begin{array}{l}\text { Money Laundering } \\
\text { and } \\
\text { Misappropriation of } \\
\approx 25 \mathrm{bn}\end{array}$ & $\begin{array}{l}13 \text { Years } \\
\text { Imprisonment }\end{array}$ \\
\hline 7. & Orji Uzor Kalu & Abia State Governor & $\begin{array}{l}\text { Embezzlement and } \\
\text { Fraud worth of } \\
\$ 7.65 \mathrm{bn}\end{array}$ & $\begin{array}{l}12 \text { Years } \\
\text { Imprisonment }\end{array}$ \\
\hline
\end{tabular}

Sources computed from: Lawal, N. (2019) and Ukwu, J. (2019) 
In addition, Al-Jaza'iri (1976) enumerates another dimensions of corruption and fraud prohibited by religious institution in Islam to include: presenting fake items to a person as an original one, revealing some good part of a commodity and hide its bad or corrupt side, making false oaths to somebody in business transactions or any form of dealings in a bid to regard one as being the truth bearer, trying to corrupt somebody's wealth, wife, son, servant, friend by treacherous means and betraying one's trust and to be dishonest after being entrusted with a wealth or any kind of trust.

Bellow-Imam (2004) identifies these as causes of corruption in Nigerian society: Trade restrictions, price control, government subsidies, multiple exchange rate practices, foreign exchange allocation schemes, low wages in the civil service, natural resources endowment and heavy dependence onmiscellaneous administrative instruments. In another article, Stefan (2017) highlights the effects of corruption in Nigeria, according to him, corruption undoubtedly destroys the structural well-being of a state by weakening the ability to increase revenues and imposing ever increasing tax rates. Corruption as menace increases transaction costs and creates insecurity in the economy of a state leading to ineffective economic results. Directly or indirectly, it impedes foreign direct investment and does not encourage investments in the rural and urban areas. Stefan (2017) finally concludes that corruption diminishes state ability to provide enough public goods for consumptions.

\section{The Mission of the Qur'an and the Bible}

The injunction of the Qur'an and the Bible are relatively the same in the areas of character building, reformation of the society, avoidance of immorality and establishment of unity among all the created beings, to enable our community to be worthy of living. The Qur'an attests:

Say (O Muhammad) $O$ people of the scripture (Jews and Christians): come to a word that is just between us and you, that we worship none but Allah (God) alone. And that we associate no partners with Him, and that none of us shall take others as lords besides Allah. Then if they turn away, Say: Bear witness that we are Muslims (Qur'an3:64).

The Bible also buttresses:

"I am sending you to them, to open their eyes, and turn them from darkness to light, and from the power of Satan to God, so that they may receive forgiveness of sin and a place among those who are sanctified by faith in Me" (Acts 26:17-18).

If the above quoted Qur'anic and Biblical references are critically pondered on, we could observe the similarities between the two verses in the form as well as in the contents. In brevity, the philosophy of both the Qur'an and the Bible is to consider the religious institution as a means of promoting social and economic wellbeing of their adherents as obligatory to help the orphans, elderly people, widows, poor and the needy. These and many others could be easily achieved by refraining from the sharp practices such as cheating, bribery, corruption, embezzlements, misappropriation of funds, fraud which have contributed to the unproductive economic situation in the present day Nigeria. Meanwhile, all forms and dimensions of corruption did not see the green light of religious institutions and that the perpetrators are considered to be wicked and miscreants. So, the evil of corruption has almost destabilized the 
purpose of creation, which is noted to be for the enjoyment, justice, equity and the well-being of every individual. The Qur'an affirms:

And no moving (living) creature is there on earth, but its provision is due from Allah, and he knows its dwelling place and its deposited (in the uterus or grave) all is in a clear Book (the Book of Decrees with Allah) (Q. 11:6).

The Bible also adds:

"And God blessed them, and God said unto them, be fruitful, and multiply, and replenish the earth and subdue it; and have dominion over the fish of the sea and over the fowl of the air, and over every living thing that moveth upon the earth" (Gen. 1:28).

\section{Qur'an and it Position on Corruption}

According to the Qur'an and Hadith, mitigation of corruption starts from one's belief in Allah and his submissive attitudes towards Him, His creatures and to possess qualities such as righteousness, uprightness in character building, trustworthiness, liberalities, honesty, justice, hospitality and accountability which transcends the great beyond (Basheer; 1984). Prophet Muhammad buttresses in a tradition related by Muslims:

"Whoever we assign to a public worker and conceals (take away) a needle or something above it is fraud (Ghulul) and shall definitely come with it on the Day of Judgement" (Muslim - 108).

In another elaborate version of a prophetic tradition, prophet Muhammad said:

Do not commit Ghulul (fraud) for I should not like to see anyone among you on the Day of Resurrection carrying over his neck a sheep that will be bleating, or carry over his neck of horse that will be neighing... Nor should I like to see a man carrying over his neck a camel that will be grunting... or a man carrying over his neck gold and silver and saying: "O Allah's Messenger! Intercede with Allah for me" and I will say" "I can't help you for I conveyed Allah's message to you" (Bukhari - 52). 
Allah (S.W.T) in the Holy Qur'an warns against corruption or fraud and describes it as form of looting thus:

\begin{abstract}
It is not for any prophet to take illegally a part of the booty (ghulul) and whosoever deceives (defrauds) his companions as regards the booty, he shall bring forth on the Day of Resurrection that which he took (illegally). Then every person shall be paid in full what he has earned and they shall not be dealt with unjustly (Q. 3:161).
\end{abstract}

Using false measuring device is regarded as a dishonest act in business which amounts to corrupt practices. Traders in commercial centres and market places reduce the quantity and volume of their articles of trade to maximize profits, and thereby cheating their customers. Allah in the Qur'an condemned and rebuked those who use false measure and described them as dishonest and unfaithful. The Qur'an says:

Woe to those who give less than due, who, when they take a
measure from people, take in full. But if they give by measure
or by weight to them, they cause loss. Do they not think that
they will be resurrected for a tremendous day? The day when
mankind will stand before the Lord of the world. No! indeed,
the record of the wicked is in Sijjeen. And what can make you
know what is Sijjeen? It is (their destination recorded in) a
register inscribed (Q 83:1-9).

Ruminating on the above Qur'anic and the prophetic references, we observed that Qur'an does not leave any stone unturned in standing firm against corruption or fraud in the society. Such individual, society and their leaders have a significant role to play according to the mandates of the Qur'an and Sunnah. It is inappropriate to shift the blames of immorality such as corruption and fraud on only the leaders. It is rather the joint responsibility of all. A prophetic tradition supported this as quoted by Abdul (1983) thus:

\title{
Whosever sees any abominable action let him change it with his hand; and if he is not able to do so, then with his tongue; and if he is not able to do so, then with his heart-and that is the weakest part of faith (Muslim).
}

The above tradition has made it clear that the burden of immorality in our society supposed not to be placed on leaders alone, it is rather the joint obligation of all irrespective of sex, tribe, creed or religion. In spite of the various preaching of Muslim scholars against corruption, many Nigerians, though they go to Mosques, but still engage in corrupt practices.

\section{The Position of the Bible on Corruption}

Bible in its totality has condemned corruption and other act of immorality such as bribery and fraud as inimical to the comfortability of the entire humanity. This fact is deducible through the manifestations of copious evidences from the Biblical references to be quoted later in this paper. Adrian (2007) elucidates and highlights various forms of corruption as explicitly stated in the Bible. Some of the established forms of corruption noted in the Bible include; bribery (Deut. 16:96), extortion (Isaiah 33:15), nepotism/ tribalism (1Psalm 2:12-17, 8:1-3), dishonest in business (Deut. 25:15), misuse of government property (Eph. 4:28), abuse of 
political offices (Mk. 10:42-45), favouritism (Prov. 18:5) and others numerous to be mentioned. Meanwhile, giving out something to encourage someone to grant unauthorized favour to circumvent judgements or the prescribed rules and regulations is unethical and it is against the dictates of God as exemplified in the Bible. For example, bribery and extortion (giving and demanding for gratification of any form) are strongly condemned in the Bible. The perpetrators, most especially those in position of authority should be encouraged to desist from these ungodly acts. The Bible warns:

He who walks righteous and speaks what is right, who rejects gains from extortion and keeps his hand from accepting bribes (Isaiah 33:15).

Nepotism and tribalism are other forms of corruption being perpetrated in Nigeria. So, the nature of the two are similar in operation by giving undue preferential treatments and confer unworthy advantages on someone simply because of tribal affiliation or relativity to the one in position of authority, while allocating public positions appointments or social amenities to be concentrated on a particular tribe or relative at the expense of other members of society who are equally fit to benefit are being usurped, the process may negatively affect other innocent majority. This is aptly stated in the Bible thus:

You shall not distort justice, you shall not be partial, and you shall not take a bribe, for a bribe blinds the eyes of the wise and prevent the words of the righteous (Deut. 16:19).

Nonchalant attitude displayed by some government officials against the government properties is another means of corruption in Nigeria. Instead, government appointees should see themselves as stewards who are in charge of maintaining these properties put in their care. These properties were held in trust for the citizens. Usage of these government properties or goods must require proper permission from appropriate quarters. Misuse should therefore be reported and repair should be made in case of vandalization. Appropriate rate charge should be made payable to the appropriate channels irrespective of the uses. The Bible tells us in Ephesians 4:28 that:

\section{"He who has been stealing must steal no longer, but must work doing something useful with his own hands, that he may have something to share with those in need".}

Furthermore, the reactions of the political office holders to some issues sometimes could be considered the abuse of political power which is another corrupt practice. Nigerian politicians appear to be intoxicated with unlimited power awarded themselves through the institution of immunity clause in Nigeria constitution. This has empowered some state governors to perpetrate sharp corrupt practices such as embezzlement, money laundering and misappropriation of funds, without check, they are intentionally punishing the state workers with unpaid multiple salary for months ranging from ten to thirty (10-36). For example, Oyo State Government under the leadership of Governor Isiaka Abiola Ajimobi and his counterpart Alhaji Yahya Bello of Kogi State. Despite many sermons or preaching in the Churches and Mosques that Almighty God is not in support of any misuse of power and autocratic leadership, but still they turned their deaf ears to these exhortations. An attempt to cover the atrocities committed by those state governors, they will hide themselves under the impunity and immunity clause from 
being arrested, prosecuted and convicted, because of their major and minor crimes committed. The Bible speaks:

\begin{abstract}
Jesus called them together and saith unto them, you know that they which are accounted to rule over the gentiles exercise Lordship over them: and their great ones exercise authority upon them. But so shall it not be among you: Whosoever will be great among you shall be your minister. And whosoever of you will be the chiefest shall be servant of all. For even the son of man came not to be ministered unto, but to minister and to give his life a ransom for many (Mark 10:42-45).
\end{abstract}

Favouritism is finally observed to constitute another form of corruption in Nigerian society. In some cases, human beings develop special interest, love and affection in someone at the expense of others regardless of their closeness, connectivity or family ties. The reasons for displaying favouritism may be personal due to the status. Instead of extending such to all citizens in the society, it may be limited to only the affluents, so as to avert the commensurable judgement for the crimes they might have committed. This is equally considered a corruption of the highest order, since they could be exonerated from being convicted. The Bible encourages: It is not good to be partial, to be wicked or to deprive the innocent of justice (Prov. 18:5).

Another Biblical reference attests:

Thou shalt not raise a false report: put not thine hand with the wicked to be an unrighteous witness. Thou shalt not follow a multitude to do evil: neither shalt thou speak in a cause to decline after many to wrest judgement. Neither shalt thou countenance a poor man in his cause (Exod. 23:1-3).

\title{
Conclusion
}

Corruption has been identified as the basis of poverty particularly in Nigeria. Therefore, necessary and urgent useful actions must be taken to rescue the nation's boat loaded with various corrupt practices before it capsizes. If one critically examines the social economic levels of the affected individuals in the tables above, one finds that they are either Christians or Muslims. Then religious ethical teachings supplied by Islam and Christianity have not been imbibed by their adherents in behavioural terms since corruption has permeated the nooks and crannies of Nigerian society. Thus, the essence of religious institution as a means of promoting social and economic well-being of the adherents as an obligation to help the orphans, elderly people, widows, the poor and the needy in the society could not be achieved as poverty is very rampant in Nigeria as a result of corrupt practices of Nigerians most especially those at the corridors of power. This is because the menace of corruption has rendered every aspect of Nigeria's development weakened (economically, socially, politically, etc.). It is therefore hoped that the menace of corruption and its negative effects on majority of Nigerians will be drastically reduced, the dictates of both the Qur'an and the Bible are followed with absolute loyalty, and we as well determined to do away with all acts of indiscipline that can dent the image of believers. 


\section{Recommendations}

Based on the above submissions, a comprehensive approach that may include the following recommendations should be adopted in other to achieve mitigation of corrupt practices in Nigerian society:

Importance must be attached to religious teachings in governance by allowing the religious injunctions deducible from the two sacred Books to be applied for adjudicating cases of corrupt practices as stipulated in the Shariah Law of Al-Qur'an and as exemplified as decalogue in the Bible. Political leaders are advised to shun all forms of corruption prevailing in Nigerian society to reduce the suffering of the poor masses who could not meet the target of three meals daily just because of untold hardship being experienced. The law enforcement agencies such as ICPC and EFCC should rise up to the task by making the law effective and they should discharge their responsibilities diligently and impartially, most especially in dealing with offenders of corrupt practices, regardless of their class, race or any other influence. Nigerian citizens too should be watchful of themselves in the use of government resources and see that these resources belong to others and must be shared equally.

Adherents of religions (Muslims and Christians) should be the bearers of the words of God against corruption, and they should educate their wards to follow the same patterns and familiarize them with the punishments behind their involvement in corruption in the hereafter. Media organizations like Radio, Television and Social Media should make serious campaign against corruption. Finally, groups, individuals and families should guide their younger ones to realize that corruption is against the purpose of creation. School system should make provision for the learnings about the Sacred Books of the two popular religions (Islam and Christianity) particularly about the aspect dealing with the well-being of society and its effects in the curriculum. 


\section{References}

Abdul, M. O. A. (1983). The Forty Hadith: Arabic Text, Translation and Commentaries. Lagos. Islamic Publication Bureau.

Achebe, C. (1983). The Trouble with Nigeria. Enugu. Forth Dimension Publishers.

Adetunji, B. A. (2012). An Exposition on Ethics in Islam. Abeokuta. Total Qiblah Ventures.

Adrian, A. H. (2007). Ten New Biblical Comments to Fight Corruption in Nigeria. In Abogunrin, S. O. (Ed.). Biblical Studies and Corruption in Africa (pp. 12-33) Ibadan: Nigeria Association for Biblical Studies.

Al-Jazairi, A. (1976). Minhaj al-Kabair. Al-Madinah Al-Munawwarah. Idaratul-Buhuth Publishing Company.

Basheer, A. M. (1984). Islamic Religious Knowledge. Lagos. Continental Book Centre.

Bello-Imam (2004). Corruption and National Development. Ibadan Centre for Local Government and Rural Development Studies.

Bolaji, L. (1970) Anatomy of Corruption in Nigeria. Ibadan. Daysten Press.

Hornby, A. S. Oxford Advanced Learner's Dictionary of Current English. 6th Edition. Sally Wehmeier, Oxford, England. 2001 p. 394.

John, A. (2002). Oxford School Dictionary of Word Origin. 2nd Edition Oxford University Press. New York. P. 107

Lawal, N. (2019). 13 Powerful Politicians Sent to Jail under Buhari Administration. https://www.legit.ng/am.

Mahmoud, I. S. Dictionary of Islamic Words and Expressions 3rd Edition Darussalam. Riyadh. 2011 p. 56.

Mariam-Webster, Webster's Ninth New Collegate Dictionary. Massachusetts, SA, 1990 p. 426.

Muhammad, M. K. (1996). The Noble Quran, Arabic Text, Translation and Commentaries. Riyadh. Marktabah Dar-us-Salam.

Paolo, M. (1997). Why Worry About Corruption? Washington D. C. International Monetary Fund.

Philip, M. (1997). Defining Political Corruption, Political Studies 45 (3) (Special Issue) 436462.

Richard, J. (1991). Democracy and Prebendal Politics in Nigeria. London. Cambridge University Press.

Shehu, S. (1997).Social Justice and Equity in Islam: An Unpublished Research Monograph, Development of Education. Kano. Faculty of Education. Bayero University.

Stefans, S. (2017). Corruption, Causes and Consequences. https://www.intechope. Retrived $26 / 10 / 2019$.

The Criswell Study Bible (KJV) 1979 Edition.

The Holy Bible, Revised Standard Version (1984). 
Ukwu, J. (2019). Dariye, Ibori and four other Former Nigerian Governors Convicted for Corruption Offences. https://www.legit.ng/am.

Wolf, T. and Gurgen, E. (2000). Improving Governance and Fighting Corruption in the Baltic and CIS Countries. The Role of the IMF Working Paper, Washington D.C.

Wrath, R. and Simpkings, E. (1963). Corruption in Developing Countries. London. Geoge Allen Unwin Ltd. 